Joanna Pędzisz

Uniwersytet Marii Curie-Skłodowskiej

Zakład Lingwistyki Stosowanej

\title{
ROZWÓJ KOMPETENCJI DYSKURSYWNEJ: EWALUACJA EFEKTÓW JEJ KSZTAŁCENIA
}

\begin{abstract}
Developing students' discourse competence: evaluation of a course
The purpose of this paper is to investigate the concept of discourse competence. The major part of the paper will be occupied by a summary of the findings of a qualitative study into the perceptions of discourse competence and ways it was developed with students of applied linguistics at the Maria Curie-Skłodowska University in Lublin (UMCS).
\end{abstract}

\section{Wprowadzenie}

Niemiecka szkoła dyskursu już od lat 90-tych dąży do zdefiniowania zjawiska dyskursu i określenia jego istoty. Natomiast fakt, że nasza rzeczywistość jest dyskursywna (Jäger 1996) ${ }^{1}$, a my, jako członkowie konkretnych wspólnot dyskursywnych, ich aktorzy, tę rzeczywistość kształtujemy, wskazuje na nasze kompetencje w tym zakresie.

W obliczu postulowanego ścisłego związku wiedzy jako fenomenu dyskursywnie negocjowanego w danej wspólnocie (Warnke 2009: 71) oraz języka, dzięki któremu wiedza ta jest konstytuowana i dystrybuowana (Warnke 2009:78), pojawiają się pytania: Czym jest kompetencja dyskursywna? Czy składa się na kompetencje ogólne? A może jest dominantą $w$ kształceniu językowym? W jaki sposób ją nabywamy, kształtujemy i rozwijamy?

Niniejsze rozważania wyrastają z praktycznych doświadczeń, zgromadzonych w roku akademickim 2011/2012 podczas prowadzenia ćwiczeń re-

\footnotetext{
${ }^{1}$ http://www.diss-duisburg.de/Internetbibliothek/Artikel/Wirklichkeit.html DW 24.04.2011
} 
ceptywno-dyskursywnych. Cykl kształcenia wieńczy ankieta przeprowadzona wśród studentów lingwistyki stosowanej UMCS uczestniczących w tych zajęciach. Ankieta dotyczy istoty i definicji zjawiska kompetencji dyskursywnej, możliwości jej rozwoju oraz konkretnych form jej kształtowania. Wyniki ankiety skonfrontowane zostaną z efektami kształcenia zdefiniowanymi dla całego modułu praktycznej nauki języka oraz przedmiotu Praktyczne ćwiczenia dyskursywno-receptywne w celu określenia stopnia rozwoju kompetencji dyskursywnej studentów na przestrzeni roku akademickiego. A to prowadzi tym samym do próby odpowiedzi na postawione wyżej pytania.

Zaplanowanie kolejnych faz kształcenia kompetencji dyskursywnej w ramach tych zajęć poprzedziła konfrontacja z literaturą przedmiotu, jednak była to lektura prac poświęconych teorii dyskursu, analizie dyskursu i lingwistyce dyskursu (Spitzmüller i Warnke 2011), wyrastających z tradycji lingwistyki tekstu (Heinemann i Heinemann 2002; Adamzik 2001) czy badań socjolingwistycznych (Jäger 2004).

Kwestie, jakie zostaną poruszone w artykule, dotyczą zdefiniowania i określenia istoty kompetencji dyskursywnej, form pracy w ramach ćwiczeń receptywno-dyskursywnych, które mają prowadzić do jej rozwoju oraz, co najważniejsze, ewaluacji efektów jej kształcenia, jakiej dokonali studenci trzeciego roku lingwistyki stosowanej UMCS uczestniczący w ćwiczeniach receptywno-dyskursywnych.

\section{Specyfika praktycznych ćwiczeń receptywno-dyskursywnych a kompetencja dyskursywna}

Ćwiczenia receptywno-dyskursywne znajdują się w unikatowym programie kierunku lingwistyka stosowana na każdym roku studiów w module praktycznej nauki języka. Ich cele i założenia można określić przez pryzmat efektów kształcenia obejmujących wiedzę, umiejętności i kompetencje społeczne.

\begin{tabular}{|l|l|l|}
\hline Wiedza & Umiejętności & Kompetencje społeczne \\
\hline Student wie, czym jest & Student posiada umiejętność & Student jest świadomy istnienia \\
zjawisko kompetencji & rozpoznawania i odtwarzania argu- & różnorodnych głosów w dyskursie \\
dyskursywnej i jaka jest jej & mentacji w aktualnych dyskursach & i różnej argumentacji z nimi \\
istota; & społecznych; & związanej; \\
Student ma wiedzę na & Student potrafi odnieść się do & Student jest otwarty na tę \\
temat możliwości rozwoju & stanowisk już istniejących w określo- & różnorodność i wykazuje wysoki \\
kompetencji dyskursyw- & nym dyskursie; & stopień wrażliwości wobec nich; \\
nej; & Student jest w stanie zająć & Student wykazuje autonomiczną \\
Student wie, w jaki & indywidualne stanowisko wobec & postawę wobec rozwoju kompe- \\
sposób wykorzystać & określonego tematu/ wątku określo- & tencji dyskursywnej; \\
kompetencję językową do & nego dyskursu; & Student wykazuje gotowość \\
\hline
\end{tabular}


Rozwój kompetencji dyskursywnej: ewaluacja efektów jej kształcenia

\begin{tabular}{|c|c|c|}
\hline $\begin{array}{l}\text { rozwoju i kształtowania } \\
\text { kompetencji dyskursyw- } \\
\text { nej. }\end{array}$ & $\begin{array}{l}\text { Student wykazuje umiejętność } \\
\text { tworzenia tekstów mówionych } \\
\text { i pisanych jako fragmentów dyskursu, } \\
\text { które stają się impulsem do rozwoju } \\
\text { określonego dyskursu społecznego; } \\
\text { Student jest w stanie wykorzystać } \\
\text { odpowiedni rejestr języka, by przyjąć } \\
\text { konkretną rolę społeczną oraz interak- } \\
\text { cyjną i stać się aktorem określonego } \\
\text { dyskursu. }\end{array}$ & $\begin{array}{l}\text { przynależenia do różnych wspól- } \\
\text { not dyskursywnych w zależności } \\
\text { od reprezentowanego systemu } \\
\text { wartości, stanowiska i poglądów. }\end{array}$ \\
\hline
\end{tabular}

Tabela 1: Efekty kształcenia określone dla praktycznych ćwiczeń receptywnodyskursywnych dla trzeciego roku na kierunku lingwistyka stosowana (UMCS, Lublin) ${ }^{2}$.

Wiedza dotyczy zatem istoty kompetencji dyskursywnej, możliwości jej rozwoju i relacji: kompetencja językowa a kompetencja dyskursywna. Umiejętności zakładają aktywne uczestnictwo w dyskursie poprzez działania tekstowe, dzięki którym student jako uczestnik dyskursu wchodzi w interakcję z innym uczestnikiem dyskursu w formie tekstu pisanego lub mówionego. Natomiast kompetencje społeczne gwarantują postawę otwartości studenta wobec różności stanowisk w dyskursie.

U podstaw zaproponowanej definicji kompetencji dyskursywnej, z którą konfrontowani są studenci lingwistyki stosowanej na ćwiczeniach receptywno-dyskursywnych, leży lektura obszernej literatury z zakresu lingwistyki tekstu i analizy dyskursu. A w obliczu istnienia szeregu szkół dyskursu przyjmującego różny paradygmat, definicja ta zorientowana jest na lingwistykę tekstu i określona przez Margot Heinemann i Wolfganga Heinemanna (2002) czy Kirsten Adamzik (2001). Kwestią kluczową jest więc potraktowanie dyskursu jako otwartego zbioru tekstów powiązanych ze sobą tematycznie i wchodzących w relacje wzajemnego nawiązania do treści (Adamzik 2001: 254, tłum. J.P.). W związku z tym kompetencja dyskursywna opiera się na dwóch filarach: a) umiejętności analizy tekstu wpisanego w strukturę dyskursu i b) działania oraz oddziaływania poprzez tekst na innego uczestnika dyskursu. Na kompetencję dyskursywną składają się zatem:

a. umiejętność rozpoznania związków intertekstualnych zaistniałych między tekstami należącymi do tego samego dyskursu bądź wątku dyskursu;

b. sprawność umiejscowienia tekstu jako fragmentu dyskursu w strukturze dyskursu;

\footnotetext{
${ }^{2}$ http://www.sjk.umcs.lublin.pl/sylabus/lecture/14551 DW 24.10.2012.
} 
c. zdolność rozpoznania i nazwania wątku dyskursu, w jaki wpisuje producent tekstu swoje działania poprzez tekst;

d. umiejętność określenia wydarzenia dyskursywnego, wobec którego autor tekstu zajmuje stanowisko;

e. umiejętność oddziaływania na odbiorcę poprzez tekst tzn. umiejętność dyskursywnego profilowania tekstu;

f. umiejętność odniesienia się / zajęcia stanowiska w formie tekstu mówionego lub pisanego do innego tekstu jako fragmentu dyskursu, która zakłada istnienie perspektywy dyskursywnej działań tekstowych / poprzez tekst;

g. umiejętność wykorzystania wiedzy o danym dyskursie / wątku dyskursu w zajęciu stanowiska wobec tego dyskursu / wątku dyskursu;

h. umiejętność wykorzystania wiedzy o wydarzeniu dyskursywnym w zajęciu stanowiska wobec tego wydarzenia (Pędzisz 2009: 111).

Złożoność i kompleksowość kompetencji dyskursywnej skutkuje więc wdrożeniem specjalnego programu cechującego się różnorodnością i wielowymiarowością technik, dzięki którym możliwy będzie rozwój nazwanych w definicji umiejętności i sprawności.

\section{Kompetencja dyskursywna: formy jej rozwoju}

W realizację programu ćwiczeń receptywno-dyskursywnych w roku akademickim 2011/2012 wpisane zostały zatem konkretne formy pracy, które z założenia miały prowadzić do kształtowania kompetencji dyskursywnej. Te zostaną przedstawione w kolejnych podrozdziałach.

\section{1. Ćwiczenia audytoryjne}

Ćwiczenia audytoryjne w wymiarze 30 godzin w semestrze zimowym i letnim zakładają integrację kształcenia takich sprawności językowych jak: rozumienie i tworzenie tekstów mówionych i pisanych oraz rozwój słownictwa z danego zakresu tematycznego wraz z jego wiązaniem w określone struktury gramatyczne. W oparciu o zaprezentowany poniżej cykl zajęć ukazana zostanie idea integracji poszczególnych sprawności w ramach jednego tematu: Sztuka współczesna - jej rola i status w świecie współczesnym.

I zajęcia:

1. Studenci otrzymują fotografię instalacji jako przykład sztuki współczesnej. Jest to impuls do wymiany pierwszych skojarzeń dotyczących sztuki współczesnej, jej znaczenia, próby odpowiedzi na pyta- 
nie, czym jest sztuka dziś, skąd takie pomysły artystów na „wyrażanie siebie", czy autor instalacji jest artystą? ${ }^{3}$

2. By zaznajomić się z wydarzeniem dyskursywnym, do jakiego nawiązuje fotografia, studenci otrzymują tekst opublikowany w wydaniu internetowym jednego z niemieckich czasopism, opisujący to wydarzenie. Tekst zawiera typowe ćwiczenia na rozumienie tekstu pisanego oraz pytania, jakie podejmowane są w pierwszej dyskusji na forum grupy podczas zajęć:

a. Czy instalacja jest rodzajem sztuki?

b. Co próbował osiągnąć autor tego dzieła? W jakim celu skonstruował instalację?

c. Jaka jest Twoja definicja sztuki? Jaką rolę odgrywa sztuka w życiu człowieka? ${ }^{4}$

II zajęcia:

1. Studenci pracują w 4 grupach. Każda otrzymuje 7-8 komentarzy online do tekstu, jaki analizowali. Podczas ich lektury wypełniają tabelę porządkującą informacje z tych komentarzy.

\begin{tabular}{|l|l|l|l|l|}
\hline $\begin{array}{l}\text { Temat } \\
\text { komentarza }\end{array}$ & $\begin{array}{l}\text { Autor } \\
\text { komentarza }\end{array}$ & $\begin{array}{l}\text { Prezentowane } \\
\text { stanowisko/ } \\
\text { Argumentacja }\end{array}$ & $\begin{array}{l}\text { Interesujące/ } \\
\text { kontrowersyje } \\
\text { cytaty z komentarzy }\end{array}$ & $\begin{array}{l}\text { Wyrażanie opinii/ } \\
\text { emocji: środki } \\
\text { językowe }\end{array}$ \\
\hline & & & & \\
\hline
\end{tabular}

Tabela 2: Tabelaryczna forma porządkowania informacji zawartych w komentarzach online.

\footnotetext{
${ }^{3}$ Studenci otrzymali fotografię instalacji Martina Kippenbergera pt.: Wenn's anfängt durch die Decke zu tropfen, o której stało się głośno w Niemczech, gdy pani sprzątająca w muzeum w Dortmundzie uznała, że plamy w czarnym pojemniku, to brud i próbowała je wyczyścić, a te były elementem instalacji. W ten sposób, jak donosiły media, zniszczyła dzieło sztuki warte tysiące euro. Jest to wydarzenie nagłośnione w mediach, w związku z tym zyskuje status dyskursywnego.

${ }^{4}$ Podczas pracy nad określonym zakresem tematycznym studenci konfrontowani są z różnymi tekstami i różnymi gatunkami tekstowymi, jakie należą do omawianego zakresu tematycznego. Ćwiczenia do tekstów otrzymują zawsze na tydzień przed planowanymi zajęciami, by mieli czas na ich opracowanie, przygotowanie się, zaznajomienie z tematem, pracę ze słownictwem, strukturami gramatycznymi itd. Określony tekst stanowi zawsze punkt wyjścia do dalszej pracy nad tematem, a zatem stałym elementem materiału do przygotowania są tzw. pytania do dyskusji, które jeszcze przed jej rozpoczęciem ją profilują, skupiają uwagę studenta na określonym aspekcie podejmowanym potem $\mathrm{w}$ dyskusji.
} 
Każda grupa ma wypracować w oparciu o uporządkowane informacje mapę myśli, obejmującą tematy, podtematy, aspekty tematów. W ten sposób studenci samodzielnie tworzą hierarchię struktury tematycznej analizowanych komentarzy.

2. Na forum każda grupa referuje efekty swojej pracy, tak by pozostałe grupy uzupełniły swoje tabele.

3. Cała grupa pracuje w oparciu o małe mapy myśli i wypracowuje dużą mapę myśli, która obejmuje wszystkie wątki podejmowane przez internautów w ich komentarzach. W ten sposób tworzą strukturę tematyczną dyskusji online, jaka rozgorzała po wydarzeniu. Studenci samodzielnie muszą zadecydować, co stanowi wątek, jakie tematy go tworzą, co jest aspektem tematu itd.

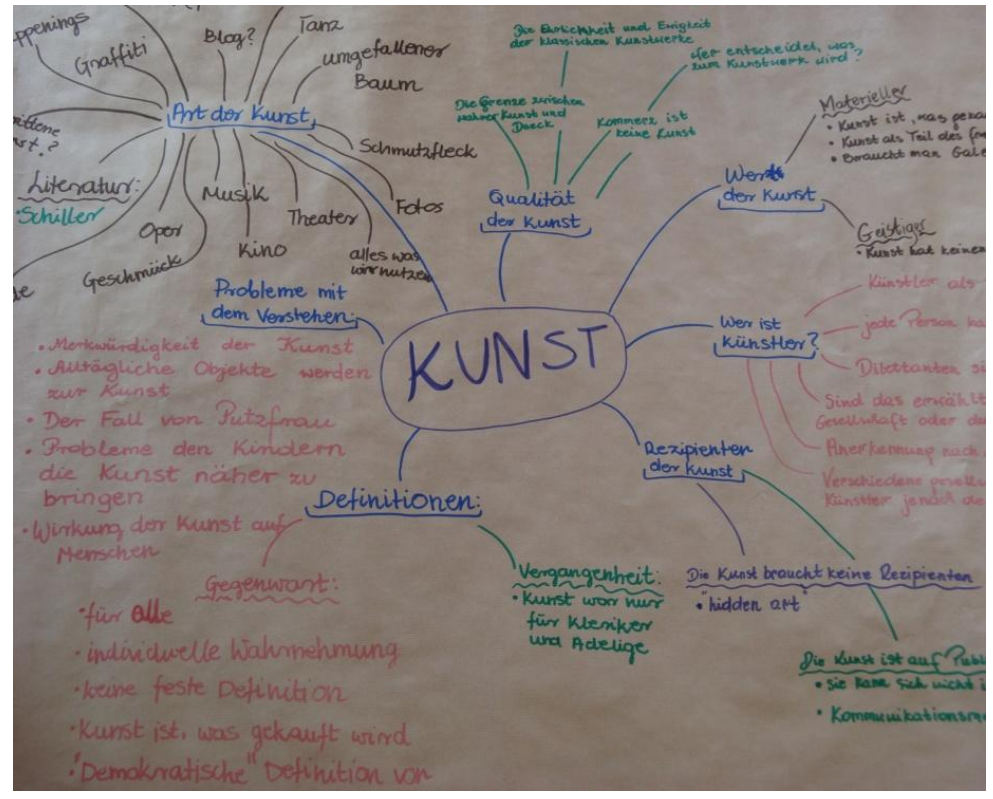

Ilustracja 1: Mapa myśli skonstruowana przez studentki lingwistyki stosowanej UMCS (3 rok, grupa angielsko-niemiecka).

III zajęcia poświęcone zostają pracy nad leksyką oraz ćwiczeniu wieńczącemu omawiany temat: linii argumentacyjnej, która zawiera elementy dramy. Prowadzący symbolizuje tezę, natomiast studenci argumenty. Każdy z nich ustawia się w sali wobec tezy w zależności od tego, czy się z nią zgadza (najbliżej tezy), rozważa za i przeciw (w środku), czy poddaje ją w wątpliwość (najdalej tezy). Studenci uzasadniają swoje stanowisko. Linia argumentacyjna stanowi przyczynek do dalszej dyskusji, do rozwoju już istniejących argumentów, po- 
jawienia się nowych. Zadanie domowe po cyklu zajęć polega na zabraniu głosu w dyskusji na forum internetowym zatytułowanym: Kunstliebhaber ergreifen das Wort (Miłośnicy sztuki zabieraja głos.)

\subsection{Warsztaty dyskursywne}

Warsztaty dyskursywne prowadzone są w formie zajęć fakultatywnych, w wymiarze dwóch godzin tygodniowo. Mają one formę otwartą. Studenci nie są zobligowani do przygotowania określonego materiału. Ich punktem ciężkości jest rozwój umiejętności tworzenia tekstów mówionych, spontanicznego reagowania, argumentowania, analizy i konfrontacji ze stanowiskiem drugiej osoby w sytuacji dyskusji na forum. A zatem forma pracy (dyskusja na forum) oraz zakres kształcenia sprawności językowych (tworzenie tekstów mówionych) jest ograniczony. Jednak dobór tych właśnie form wypływał z potrzeb, jakie zasygnalizowali studenci na początku roku akademickiego. Prowadzący daje impuls do dyskusji, ewentualnie wspomaga ją w krytycznych fazach dodatkowymi pytaniami, gdy zaistnieje problem z jej kontynuacją.

Przykładowe zadania otwierające dyskusję:

1. Trzy słowa-klucze np. laptop, pokolenie, kryzys. Studenci próbują odszukać związki znaczeniowe między tymi słowami, powiązać je ze sobą tematycznie;

2. Tekst z lukami (wiersz lub piosenka). Studenci tworzą własną wersję tekstu, uzasadniają swój wybór i dobór słów wstawionych w luki, konfrontują z wersjami koleżanki / kolegi. W tym ćwiczeniu studenci odkrywają swój potencjał możliwości językowych, ale również wielość koncepcji i „pomysłu na tekst”. Studenci otrzymują w drugiej fazie ćwiczenia oryginalną wersję tekstu i porównują z własną wersją, co stanowi kolejny impuls do dyskusji. Tym razem wiąże się ona z wielością interpretacji jednego tekstu;

3. Tytuły artykułów należących do tego samego wątku dyskursywnego bądź tematyzujące jedno wydarzenie dyskursywne. Studenci spekulują, jakiemu wątkowi przypisać teksty, aktywizują zasoby wiedzy na temat dyskursu, wydarzenia dyskursywnego, wątku. Dopiero w drugiej fazie otrzymują teksty i zapoznają się z ich treścią, określają, na ile potwierdziły się ich spekulacje;

4. Tekst. Studenci muszą znaleźć tezę w tekście, która ich zdaniem jest intrygująca /kontrowersyjna/ godna zainteresowania i podjęcia jej w dyskusji.

\footnotetext{
${ }^{5}$ Wbrew pozorom nie jest to łatwe ćwiczenie. Jedna ze studentek stwierdziła: „To nie jest wcale takie proste. Gdyby Pani zapytała: Co sądzicie na ten temat, zajmijcie
} 


\subsection{Praca z nowymi mediami}

Zadania na platformie moodle, jaką do dyspozycji mają studenci lingwistyki stosowanej UMCS, dają możliwość wspomagania procesu kształtowania kompetencji dyskursywnej nowymi mediami. Obejmują one głos na forum internetowym, quizy, możliwość zamieszczania dodatkowych tekstów i zadań do nich. Zadania te są wpisane w cykl zajęć audytoryjnych lub mają charakter fakultatywny, ale wpisują się w zakres tematyczny aktualnie omawiany w ramach zajęć audytoryjnych. Studenci mogą również wykorzystywać pracę z blogosferą a blog "Gedankenanstoß” zawiera materiał do skomentowania np. obraz, pliki video lub teksty. W przypadku tych dwóch form pracy zakres kształcenia sprawności językowych ogranicza się do tworzenia tekstów pisanych, głównie jednej formy: komentarza online, jednak bardzo popularnego, w medium jakim jest Internet. Te zadania cieszyły się jednak niezbyt dużą popularnością. Uzasadnienie tego faktu znalazło się w końcowej ankiecie, przeprowadzonej wśród studentów, której wyniki szczegółowo omówione zostaną w rozdziale czwartym tego artykułu.

\subsection{Teczka z dodatkowymi tekstami}

Teczkę z dodatkowymi tekstami studenci składają po semestrze pracy. Tym samym dokumentują swoją samodzielną pracę. Teczki mogą zawierać teksty, jakie studenci przeanalizowali oraz napisali do nich komentarze $w$ dowolnej formie np. wiersz, kartka z pamiętnika, sprawozdanie, rozprawka, monolog wewnętrzny itp. W tym przypadku należy pozostawić studentom wolną rękę co do doboru tekstów. Mogą one poruszać tematy, które leżą w kręgu zainteresowań konkretnej osoby, bądź teksty, które były rozwinięciem tematów znajdujących się w programie zajęć. Przykładowe teczki, jakie złożyli studenci lingwistyki stosowanej zawierają różne gatunki tekstów i cechuje je duża rozpiętość tematyczna. Znalazły się tam:

a. komentarze do wydarzeń dyskursywnych, jak np. śmierć Vaclava Havla. Reakcją na to wydarzenie jest krótki komentarz: Ein guter Politiker (Dobry polityk);

b. kartka z pamiętnika o podróżach;

c. refleksja na temat graffiti, jakie Autorka ogląda codziennie idąc na uczelnię;

stanowisko wobec tej tezy... Ale ja sama muszę zdecydować". Natomiast kompetencja dyskursywna zakłada właśnie tę umiejętność. Student powinien sam wiedzieć, co go intryguje, z czym się nie zgadza, co wywołuje jego protest, a co jego aprobatę. 
d. głos w dyskursie na temat globalizacji;

e. recenzja filmu „Dying To Dance”;

f. komentarze do artykułów wpisujących się w wątek dyskursu: relacje między kobietami i mężczyznami.

Wątpliwość, jaka zrodziła się w trakcie trwania semestru, dotyczyła skuteczności tej formy. Wątpliwość ta została potwierdzona wynikami ankiety końcowej. Jej skuteczność oceniana była między 3 a 4 w sześciostopniowej skali. By nie rezygnować $z$ tej formy, należy ją włączyć na stałe w cykl zajęć audytoryjnych. Dodatkowe teksty gromadzone do teczki, można ograniczyć do zakresów tematycznych omawianych w ramach ćwiczeń audytoryjnych. Ostatnie zajęcia zamykające określony zakres tematyczny mogą mieć formę warsztatów, w ramach których studenci prezentują wyniki swojej dodatkowej pracy i dokumentują je nie tylko napisanymi tekstami, ale słownikami tematycznymi, dalszą argumentacją rozwijającą zakres tematyczny o dodatkowe kwestie $w$ formie np. map myśli.

\section{Skuteczność form pracy: Wyniki ankiet}

Ankieta przeprowadzona została w grupie 23 osób. Nie jest to grupa reprezentatywna, dlatego też wyniki należy traktować jako studium przypadku, ukazujące tendencje, które będą wymagały oczywiście potwierdzenia i zweryfikowania $w$ dalszych badaniach. Celem ankiety było a) określenie stopnia rozwoju kompetencji dyskursywnej studentów po dwóch semestrach zajęć z wykorzystaniem opisanych form, b) określenie skuteczności tych form w rozwoju kompetencji dyskursywnej, w oparciu o formy pracy na zajęciach, c) określenie istoty zjawiska kompetencji dyskursywnej.

W sześciostopniowej skali stopień rozwoju kompetencji dyskursywnej studenci określają między 4 a 6 . Preferowane i według studentów najbardziej skuteczne formy pracy, które przyczyniły się do jej rozwoju, to dyskusja na forum grupy i dyskusja w grupach w ramach zajęć audytoryjnych. Uznaniem cieszy się również samodzielna praca $w$ oparciu o materiał, jaki studenci mają przygotować na zajęcia (ćwiczenia do tekstów). Znacznie niżej ocenione zostały ćwiczenia i fora dyskusyjne umieszczane na platformie moodle oraz teczka z dodatkowymi tekstami.

W uzasadnieniu swoich wyborów studenci podkreślają, że dyskusje na forum grupy lub w grupach rozwijają umiejętność swobodnego wyrażanie własnych myśli, argumentowania, odnoszenia się do punktu widzenia współrozmówcy, reagowania na jego argumentację, pozwalają na poznanie opinii innych. Dzięki takim dyskusjom poszerzają wiedzę na określone tematy. 
A praca z innymi jest ciekawsza i motywująca. Studenci widzą ścisły związek między pracą z materiałem do przygotowania przed zajęciami a dyskusjami na forum grupy. Praca z materiałem wymaga gruntownej jego analizy, pozwala na zgromadzenie informacji na dany temat, uporządkowania ich i wykorzystania w argumentacji podczas dyskusji na forum grupy. Materiał taki poszerza wiedzę na dany temat i utrwala ją.

Niższe oceny przypisane ćwiczeniom i forom dyskusyjnym na platformie moodle oraz teczce $z$ dodatkowymi pracami wynikają ze zbyt małej motywacji do korzystania z kampusu oraz zbyt małej ilości czasu poświęconego na przygotowanie teczki. Choć zdarzały się wypowiedzi, które podkreślały korzyści takich form, jak stała dostępność ćwiczeń na kampusie, dzięki czemu można je zrobić w każdej chwili i nie ma ograniczeń czasowych dla ich realizacji. Student sam może zadecydować, kiedy do nich sięgnąć. Pisanie dodatkowych tekstów do teczki rozwija własne zainteresowania poprzez brak ograniczenia tematycznego dla tych tekstów.

Po dwóch semestrach studenci potrafią określić mocne i słabe strony swojej kompetencji dyskursywnej, a zatem wiedzą, co potrafią, a nad czym powinni jeszcze popracować. Dzięki pytaniom: Co składa się na mojq kompetencję dyskursywnq? Co umiem? Nad czym muszę popracować? wykazali więc skłonność do autorefleksji. Ta daje nadzieję na to, że studenci znają swój potencjał i będą chcieli go wykorzystać do dalszej pracy nad rozwojem kompetencji. Mocne strony widzą w umiejętności argumentowania, wyrażania własnej opinii, umiejętności zajmowania stanowiska wobec określonej kwestii. Co istotne, studenci podkreślali pokonanie barier przed mówieniem w języku obcym i kreatywność w tworzeniu swoich wypowiedzi, która wiąże się z umiejętnością argumentowania. Studenci w swoich wypowiedziach nie odtwarzali znanych argumentów, pojawiających się w analizowanych tekstach, ale rzeczywiście prezentowali własne, indywidualne stanowisko. W tym kontekście można mówić o kreatywnym wymiarze tworzonych wypowiedzi. Studenci wskazali dwa obszary, w których mają problemy: gramatyka, słownictwo oraz płynność wypowiedzi. Nazwali również czynniki, których nie wiązali bezpośrednio z ich kompetencją językową, a mianowicie: stres, jaki towarzyszy ich wypowiedziom oraz trudności w sprzeciwianiu się czyimś argumentom.

Większość studentów chce rozwijać kompetencję dyskursywną poprzez rozwijanie sprawności mówienia, czytania i poszerzanie słownictwa. Chcą tworzyć prace pisemne do publikacji np. w Internecie i angażować się na forach internetowych. A zatem należy w przyszłości wskazać studentom fora o dobrej renomie, na których zetkną się z interesującymi internautami i ciekawą tematyką. W ramach zajęć audytoryjnych należy również zająć się takimi gatunkami tekstów, które są najbardziej popularne w sieci - komen- 
tarz online czy blog oraz systemami, w jakich te teksty funkcjonują np. twitter. Studenci wiedzą, że poszerzając wiedzę i zdobywając pewność siebie podczas wypowiedzi, przyczyniają się do rozwoju kompetencji dyskursywnej.

Rozpoczynając pracę $w$ tym roku akademickim studenci kojarzyli z kompetencją dyskursywną głównie sprawność mówienia. Na pytanie: Co wiedziałam/tem na temat kompetencji dyskursywnej? dominowały odpowiedzi: umiejętność wypowiadania się swobodnie na każdy temat, bycie dobrym słuchaczem i współrozmówcą. A zatem uwypuklony został aspekt interakcyjności podczas tworzenia wypowiedzi ustnej. Natomiast studenci nie wiążą już jednoznacznie doboru argumentów i umiejętności wyrażania opinii z tekstami mówionymi. Również nie widzą relacji pomiędzy wiedzą a umiejętnością argumentowania. Kwestie, jakie studenci łączą po tym roku akademickim z kompetencją dyskursywną to:

a. zdolność krytycznej analizy tekstów i wypowiedzi, co wskazuje na rozróżnienie formy pisemnej i ustnej tej kompetencji;

b. wykorzystanie informacji z różnych dziedzin życia, poszerzenie wiedzy ${ }^{6}$;

c. świadomość, że obejmuje ona znacznie więcej aspektów niż tylko mówienie

Ta ostatnia, nieco enigmatycznie brzmiąca uwaga, dowodzi rodzenia się świadomości kompleksowego charakteru kompetencji dyskursywnej, co stanowi wyzwanie dla prowadzącego, by tę świadomość utrwalać i wzmacniać. Podsumowując powyższe rozważania, dotyczące kształtowania kompetencji dyskursywnej, należy podkreślić z całą stanowczością, że propozycja jej definicji jest jak najbardziej koncepcją otwartą, która być może zapoczątkuje dyskurs o kompetencji dyskursywnej, również w kontekście zintegrowanego kształcenia sprawności językowych na różnych etapach edukacyjnych.

\section{BIBLIOGRAFIA}

Adamzik, K. 2001. Sprache: Wege zum Verstehen. Tübingen/ Basel: A. Francke Verlag Heinemann, M. i Heinemann, W. 2002. Grundlagen der Textlinguistik. Interaktion Text - Diskurs. Tübingen: Max Niemeyer Verlag.

Jäger, S. 1996. Die Wirklichkeit ist diskursiv. http://www.diss-duisburg.de/Internetbibliothek /Artikel/Wirklichkeit.html DW 24.04.2011

Jäger, S. 2004. Kritische Diskursanalyse. Eine Einführung. Münster: UNRAST-Verlag

\footnotetext{
${ }^{6} \mathrm{~W}$ tych odpowiedziach pojawia się zatem już tendencja do łączenia wiedzy ogólnej i z danego zakresu tematycznego z kompetencją językową, ponieważ wiedza warunkuje umiejętność argumentowania i określania stanowiska wobec problemu.
} 
Pędzisz, J. 2009. « Blog jako narzędzie wspierające rozwój kompetencji dyskursywnej ». (w) Neofilolog, nr 33 (red. K. Karpińska-Szaj i S. Chudak). Poznań: 101-112.

Spitzmüller, J. i Warnke, I. H. 2011. Diskurslinguistik. Eine Einführung in Theorien und Methoden der transtextuellen Sprachanalyse. Berlin/Boston: Walter de Gruyter. Warnke, I. 2009. « Zur wissenskonstitutiven Funktion des Diskurses - Wissen, soziale Kontrolle und Sprache ". (w) Diskurse als Mittel und Gegenstände der Germanistik (red. F. Grucza, G. Pawłowski i U. Reinhold). Warszawa: Wydawnictwo Euro-Edukacja: 71-84.

\section{Źródła internetowe}

http://www.sjk.umcs.lublin.pl/sylabus/lecture/14551 DW 24.10.2012 